\title{
Physiological impact of putrescine on Trigonella foenum-graecum L. growing under temperature stress
}

\author{
Mohamed OSMAN ${ }^{1}$, Soad EL-FEKY ${ }^{1}$, Horia SELIEM ${ }^{1}$, Shaimaa ABO-HAMAD ${ }^{1 \star}$
}

\begin{abstract}
It is important to determine the effect of the rapid environmental changes on plant physiological processes which were reflected on plant production and find the ways to alleviate their effects. This study was performed to study the role of putrescine in ameliorating the harmful effects induced by temperature stress. Priming treatment was applied to Trigonella by soaking the seeds in $5 \mathrm{mM}$ putrescine before exposure to the different temperature degrees $\left(15^{\circ} \mathrm{C}, 25^{\circ} \mathrm{C}, 35^{\circ} \mathrm{C}\right.$ or $\left.40^{\circ} \mathrm{C}\right)$. At the age of 120 days old some yield parameters and physiological processes were measured. The results indicated that, $15^{\circ} \mathrm{C}, 35^{\circ} \mathrm{C}$ or $40^{\circ} \mathrm{C}$ significantly decreased the yield parameters, carbohydrates and soluble proteins. Amino acids and phenols are accumulated in seeds which is considered an acclimation mechanism of plant against temperature stress. The results also, indicated an increase in the total unsaturated fatty acids and a decrease in the thickness and intensity of the $\beta$-esterase isoforms in plant seeds subjected to $15^{\circ} \mathrm{C}$ and $35^{\circ} \mathrm{C}$. Temperature stress affects the plant production and application of putrescine improves the harmful effects.
\end{abstract}

Keywords: $\beta$-esterase; fatty acids; fenugreek; polyamines; temperature stress.

Practical Application: This work clarified the role of natural and safe compound (putrescine) in inducing an important primary and secondary metabolites in Trigonella plant growing under optimum temperature and also under temperature stress. Trigonella is a winter plant, it is an important medicinal plant and has a great therapeutic effect; it is natural antioxidant source acts as anticancer, decreases serum total lipids and serum cholesterol, enhances insulin sensitivity, and has antidiabetic effect.

\section{Introduction}

Plants are continuously exposed to a variety of adversely changing environmental conditions such as heat, cold, drought, light, increasing acidity or alkalinity and metal damage, which affect plant growth, distribution and productivity (Ahmad et al., 2008; Jeong et al., 2018). These stressful conditions are associated with great losses in the productivity of many of the agriculturally important crops and hence, affect on the economic returns of many countries. Thus, concerted efforts are exerted to understand the mechanisms of plant resistance against the different stresses.

Temperature stress is one of the most important abiotic factors that limit the plant production (Kumar et al., 2010; Gaur et al., 2015). Crops are exposed to a wide range of fluctuations in temperature under natural growth conditions. Temperature instabilities can be experienced by crops at macro or micro-environment levels, but both of them can have significant implications on normal growth and production. Climatic hazards are possible to increase in the near future and plants will face lethal temperature degrees which lead to a pragmatic shift in temperature zones, differential patterns of rainfall and agricultural production belts.

There are several natural ways of self-defense mechanisms in plants to cope the stressful conditions: they can induce several regulatory or functional genes (Bartels \& Sunkar, 2005) or can make different biochemical or physiological changes. The accumulation of some osmolytes, such as sugars, alkaloids, amino acids and protective proteins, is an important element of the biochemical and physiological response of plants to the stressful conditions (Liu et al., 2007; Ahmad et al., 2011; Osman et al., 2015). In addition to these responses by the plants to the different environmental stresses, molecules known as polyamines have also been known to have an important role in response of plants to different stresses (Bouchereau et al., 1999; Chen et al., 2019).

Polyamines (putrescine, spermine, spermidine and cadaverine), are the widely distributed nitrogen containing organic substances. They were discovered more than 100 years ago. In plants, polyamines have been associated with regulating many physiological processes, such as embryogenesis, organogenesis, floral initiation and development, leaf senescence, fruit development and ripening, and biotic and abiotic plant stress responses (Kumar et al., 1997; Bagni \& Tassoni, 2001; Kusano et al., 2008).

\section{Materials and methods}

Seeds of Trigonella foenum-graecum were obtained from Sakha Research Institute, Sakha, Egypt. During the growth season (November and December), the seeds were sterilized by immersing them in $0.01 \% \mathrm{HgCl}_{2}$ for 1 minute then washed several times with distilled water. The seeds were divided into two sets. The first was soaked in distilled water and the second 
was soaked in $5 \mathrm{mM}$ putrescine for 2 hours. Each set of seeds was divided into two groups. The first group of each set was sown in pots ( 5 seeds / pot) containing clay-sandy soil (2:1). The second group of each set was germinated for 5 days and then the seedlings were exposed to $15^{\circ} \mathrm{C}, 35^{\circ} \mathrm{C}$ or $40^{\circ} \mathrm{C}$ for 4 hours. The plants were left to grow till the end of the season and irrigated with tap water under greenhouse conditions. A completely random design was used and each treatment was replicated 5 times. At the end of the growth season (120 days old), plants were collected and the following measurements were carried out: (1) Yield parameters (number of pods per plant, number of seeds per pod, weight of pod with seeds and weight of 1000 seeds). (2) Biochemical analysis: carbohydrates, proteins, amino acids, phenols, fatty acids and isozymes in the harvested seeds.

\subsection{Estimation of carbohydrates}

Extraction and clarification of the carbohydrates from the dried seeds was performed according to Naguib et al. (1968).

\section{a) Determination of direct reducing value (DRV).}

Monosaccharides were estimated in seeds of Trigonella colorimetrically using a modified Nelson reagent (Naguib, 1964). The monosaccharides concentration was calculated as mg glucose / g dry wt.

\section{b) Determination of total reducing value (TRV).}

Invertase enzyme was used in hydrolysis of sucrose. After hydrolysis, the produced monosaccharides were estimated as DRV. The difference between TRV and DRV is used as an estimation of sucrose as $\mathrm{mg}$ glucose / $\mathrm{g}$ dry wt.

\section{c) Extraction and estimation of polysaccharides}

Extraction and estimation of polysaccharides were carried out according to the procedures adopted by Naguib (1963). The concentration of sugars was calculated as mg glucose / g dry wt.

\subsection{Estimation of total soluble proteins.}

Total soluble proteins in dry seeds were assayed quantitatively in the borate buffer extract using the method described by Bradford (1976). The content of proteins in seeds was calculated as $\mathrm{mg} / \mathrm{g}$ dry wt. using a calibration curve of Bovine Serum Albumin protein.

\subsection{Determination of amino acids}

Amino acids content was estimated by Ninhydrin assays using the method described by Lee \& Takahashi (1966). The amino acids content was calculated as mg / g dry wt. using a prepared calibration curve by glycine.

\subsection{Estimation of total phenolic compounds}

Total phenolic content in Trigonella seeds was determined quantitatively using the method described by Jindal and Singh
(1975). A standard curve was made using gallic acid and used for the determination of phenolic compounds as $\mathrm{mg} / \mathrm{g}$ dry wt.

\subsection{Estimation of fatty acids}

Transmethylation of lipids and extraction of fatty acids methyl esters was carried out as described by Garces \& Mancha (1993). Fatty acids methyl esters were analysed using gas chromatography (GC, Hewlett Packer D, HP 6890, series).

\subsection{Isozymes analysis}

The plant samples were ground and extracted on ice with 0.1 M Tris-HCl buffer, $\mathrm{pH} 7.5$ containing $0.01 \mathrm{M}$ EDTA, $0.01 \mathrm{M}$ potassium chloride, $0.01 \mathrm{M}$ magnesium chloride hexahydrate, 0.1 M D.T.T (di-thioteritol), 4\% P.V.P (poly vinyl pyrolidone) and $10 \%$ sucrose (Gottlieb, 1981). The extracts were centrifuged at $18000 \mathrm{rpm}$ for 20 minutes, at $4{ }^{\circ} \mathrm{C}$ and then stored in a deep freezer at $-80{ }^{\circ} \mathrm{C}$ until use. The extracts were separated on $10 \%$ PAGE polyacrylamide (Laemmli, 1970; Pasteur et al., 1988).

\subsection{Esterase, EST ( $\beta$-naphthyl acetate)}

Gels were incubated in $100 \mathrm{ml} 0.05 \mathrm{M}$ phosphate buffer (pH 7.2) containing $50 \mathrm{mg}$ Fast Red TR and $10 \mathrm{mg} \beta$-naphthylacetate dissolved in $1 \mathrm{ml}$ of acetone, in the dark at $37^{\circ} \mathrm{C}$ until bands appeared. The gels were washed in water and fixed in $3 \%$ acetic acid. For reduction of nonspecific background, 2 to $5 \mathrm{~mL}$ of $4 \%$ formaldehyde was added to the staining solution (Manchenko, 1994).

\subsection{Statistical analysis}

The obtained results were statistically analysed using the analysis of variance test (ANOVA) described by Bishop (1983).

\section{Results and discussion}

Temperature extremes, both low (cold stress) and high (heat stress), are injurious to plants at all stages of growth, resulting in severe loss in productivity of crops (Bhandari et al., 2017). The results of this investigation revealed that the increase $\left(35^{\circ} \mathrm{C}\right.$ and $40^{\circ} \mathrm{C}$ ) or decrease $\left(15^{\circ} \mathrm{C}\right)$ in temperature beyond the optimum temperature $\left(25^{\circ} \mathrm{C}\right)$ caused a significant reduction in the measured yield parameters (number of pods / plant, number of seeds / pod, weight of pod with seeds and weight of 1000 seeds) (Figure 1). Plants subjected to $40{ }^{\circ} \mathrm{C}$ heat stress were severely affected. Their were a decrease in number of seeds per pod by $75 \%$ and in weight of pod with seeds by $74.1 \%$ when subjected to $40{ }^{\circ} \mathrm{C}$ compared with control at $25^{\circ} \mathrm{C}$. These results are in accordance with those obtained by Prasad et al. (2008), who found that high temperature decreased Sorghum height, seed set, seed yield, seed numbers and seed size. Also, Barutcular et al. (2017) proved that warm environment (heat stress) caused a significant reduction in grain yield and physiological parameters of wheat plant by about $54 \%$ and $32 \%$ in 2007-2008 and 2008-2009 growth seasons respectively. Treatment of Trigonella seeds with $5 \mathrm{mM}$ putrescine before exposing to temperature stress degrees removed the harmful effects induced by temperature stress on the measured yield parameters (Figure 1). Exogenous application of polyamines stimulates tolerance to high or low temperatures in 

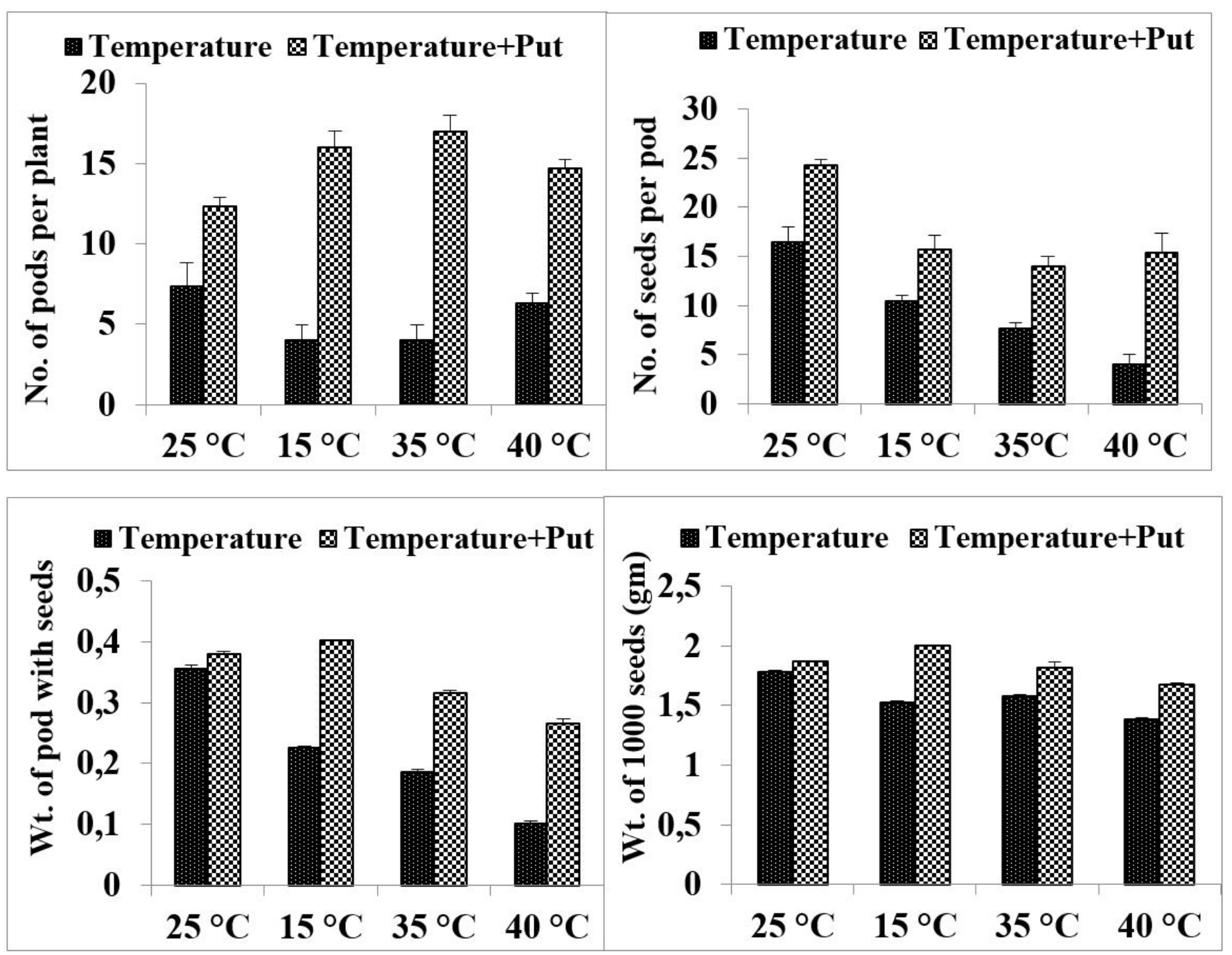

Figure 1. Effect of Putrescine on yield parameters of 120 days old Trigonella foenum-garcum plant under temperature stress.

various crop plants (Perez-Amador et al., 2002; Tajti et al., 2018). It was found that putrescine improves the yield and quality of bell pepper (Mahmood et al., 2017) and broccoli (Zheng et al., 2019). The exogenous application of putrescine led to accumulation of endogenous polyamine contents in plants (Kubis et al., 1991; He et al., 2002) and this may alleviate the harmful effects induced by temperature stress.

The results showed that, all the temperature stress degrees $\left(15^{\circ} \mathrm{C}, 35^{\circ} \mathrm{C}\right.$ and $40{ }^{\circ} \mathrm{C}$ ) caused a significant reduction in monosaccharides and disaccharides contents of Trigonella seeds. Monosaccharides were severely affected at $40{ }^{\circ} \mathrm{C}$ and decreased by about $89.5 \%$ compared with control at $25{ }^{\circ} \mathrm{C}$. Polysaccharides slightly decreased at $35^{\circ} \mathrm{C}$ and $40{ }^{\circ} \mathrm{C}$ compared with control samples at $25{ }^{\circ} \mathrm{C}$ (Figure 2). These reductions in sugar contents may be attributed to the highly significant decrease in photosynthetic pigments caused by $15^{\circ} \mathrm{C}$ and $35^{\circ} \mathrm{C}$ in Trigonella leaves (Osman et al., 2015). In this connection, Wolf et al. (1982) found that sucrose concentration was decreased by $56 \%$ in soybean seeds subjected to cold stress $\left(15^{\circ} \mathrm{C}\right)$. Putrescine alleviated the deleterious effects of temperature stress on carbohydrate contents of Trigonella seeds (Figure2). Putrescine improves photosynthesis process and regulates the carbohydrate metabolism (Yinghui et al., 2015). In this connection, Palma et al. (2016) showed that putrescine treatment alleviates chilling injury through modulating the carbohydrate content and this response could be due to the degradation of putrescine and the induction of amino butyric acid shunt pathway.

Proteins in general are very sensitive to any change in temperature. The protein content of Trigonella seeds (Figure 3) was significantly decreased by $50 \%$ at $15{ }^{\circ} \mathrm{C}, 27.8 \%$ at $35{ }^{\circ} \mathrm{C}$ and $69.4 \%$ at $40{ }^{\circ} \mathrm{C}$ respectively comparing to control samples. Treatment with putrescine caused a significant increase in protein content over those of the corresponding plants exposed to temperature stress alone. In this respect, Yadav et al. (2017) found that high temperature stress led to disruption of cellular membranes by increasing cell membrane injury, lipid peroxidation and $\mathrm{H}_{2} \mathrm{O}_{2}$ contents. This led to decrease in total chlorophyll and soluble proteins. Foliar application of putrescine ameliorated heat-induced damages in maize plant. 

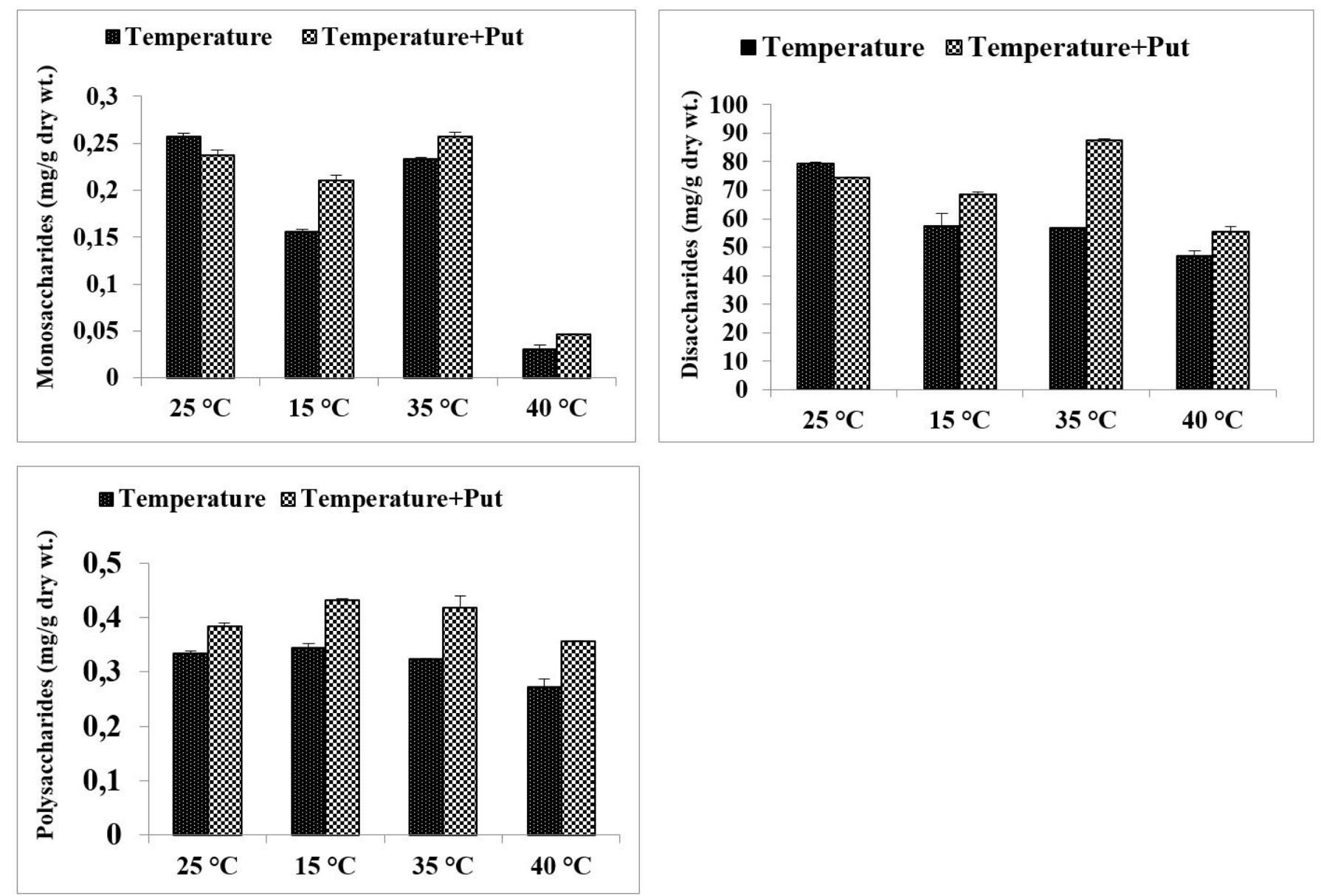

Figure 2. Effect of Putrescine on carbohydrates content (mg/g dry wt.) of 120 days old Trigonella foenum-garcum seeds under temperature stress.

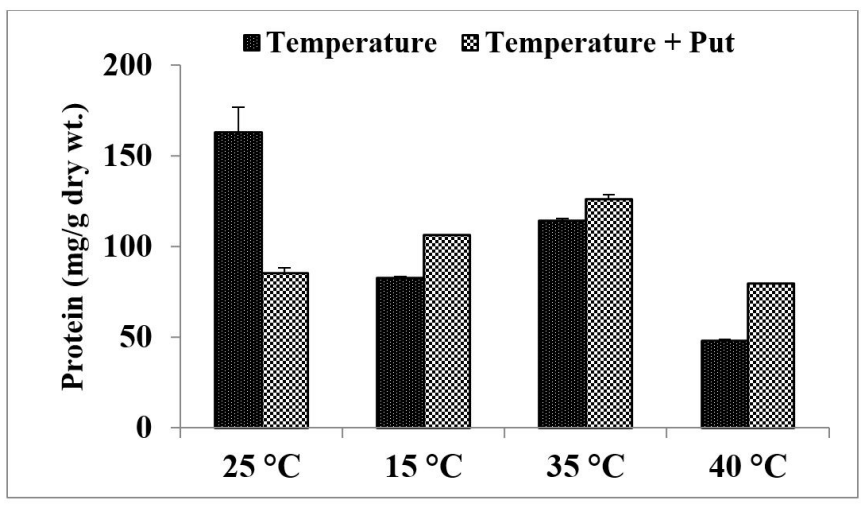

Figure 3. Effect of Putrescine on protein content (mg/g dry wt.) of 120 days old Trigonella foenum-garcum seeds under temperature stress.

Amino acids in general and specifically proline are accumulated in plants in response to different abiotic stresses. In this study, we found a significant increase in total amino acids of Trigonella seeds when subjected to different stress temperature degrees $\left(15^{\circ} \mathrm{C}, 35^{\circ} \mathrm{C}\right.$ and $\left.40^{\circ} \mathrm{C}\right)$ compared with control $\left(25^{\circ} \mathrm{C}\right)$. This increase was magnified by application of putrescine (Figure 4). The increase in amino acids contents may be considered as acclimation mechanism of plant against temperature stress. Among the different amino acids, proline protects plant

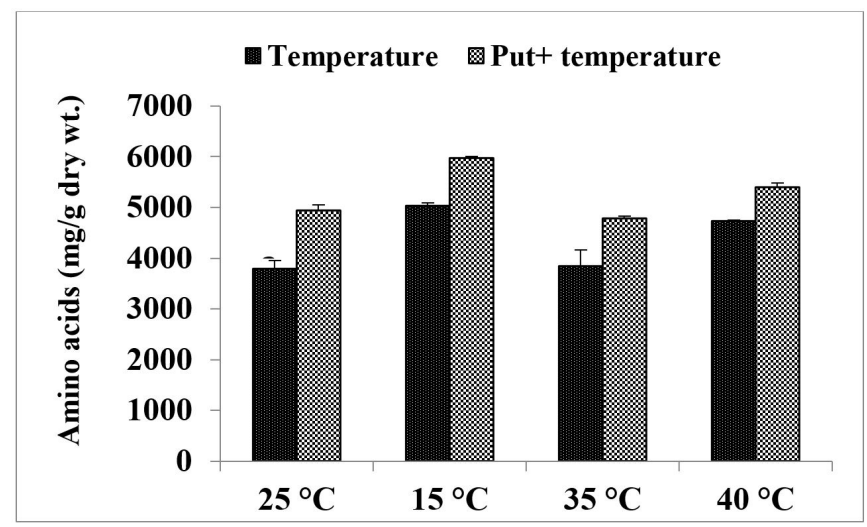

Figure 4. Effect of Putrescine on total amino acids content (mg/g dry wt.) of 120 days old Trigonella foenum-garcum seeds under temperature stress.

tissues against different abiotic stresses by acting as osmotically active solute, nitrogen storage compound and protectant for enzymes and other cellular structures (Chai et al., 2012). In this respect, Wolf et al., (1982) stated that, amino acids composition in soybean seed in response to temperature stress was generally stable; however, there was an increase in methionine content.

The secondary metabolism is essential for the fitness of plants, many secondary metabolites play an important roles as chemical defense compounds against different stresses 
(Wink, 1997). The results showed that, phenolic compounds were accumulated in Trigonella seeds subjected to different temperature stress degrees $\left(15^{\circ} \mathrm{C}, 35^{\circ} \mathrm{C}\right.$ and $\left.40^{\circ} \mathrm{C}\right)$ compared with control. Treatment with putrescine seemed to have no significant effect on phenol contents of seeds under temperature stress (Figure 5). In accordance with our results, Rivero et al. (2001) indicated that thermal stress induces the accumulation of phenolic compounds in tomato and watermelon plants. It has been demonstrated that thermal stress induces the synthesis of phenolic compounds, such as phenyl propanoids and flavonoids (Bharti \& Khurana, 1997). Phenylalanine ammonia-lyase (PAL) is considered to be the main enzyme in the phenylpropanoid pathway (Kacperska, 1993) catalyzing the transformation, by deamination, of L-phenylalanine into trans-cinnamic acid, which is the prime intermediary in the biosynthesis of phenolic compounds (Dixon et al., 1992; Levine et al., 1994). The activity of this enzyme increases in response to thermal stress and

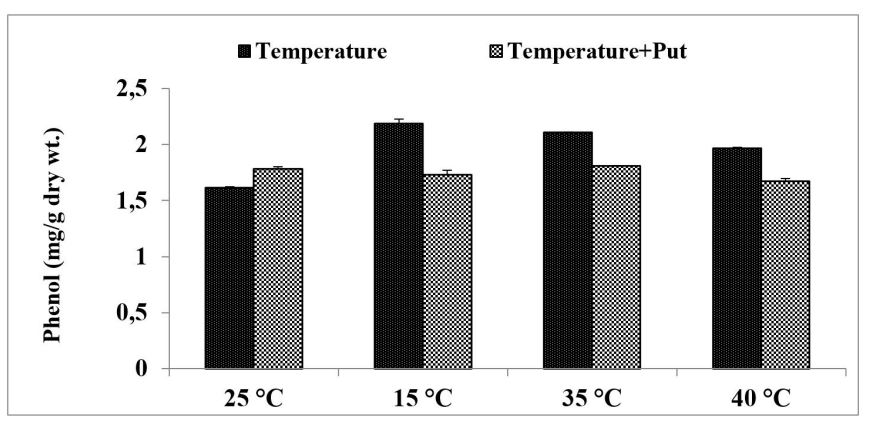

Figure 5. Effect of Putrescine on phenol content (mg/g dry wt.) of 120 days old Trigonella foenum-garcum seeds under temperature stress. is considered by many authors to be one of the main lines of cell acclimation against stress in plants (Kacperska, 1993; Levine et al., 1994; Leyva et al., 1995).

Fatty acids are important components of cellular membranes, cutin, waxes and suberin (Beisson et al., 2007). They participate in making stress resistance through the remodeling of membrane fluidity (Iba, 2002; Upchurch, 2008), the release, through lipase activity of $a$-linolenic acid (Grechkin, 1998). Free linolenic acid is considered a stress signal and the precursor for phyto-oxylipin biosynthesis (Blée, 2002). Our results indicated an increase in the total unsaturated fatty acids in plant seeds subjected to $15^{\circ} \mathrm{C}$ and $35^{\circ} \mathrm{C}$ compared with control at $25^{\circ} \mathrm{C}$ (Table 1 ). This increase was mainly due to large amounts of both $\alpha$-linolenic acid (C18:3) and oleic acid (C18:1). In this respect, Iba (2002) found that trienoic fatty acids (TAs) such as linolenic acid are the major polyunsaturated fatty acids in membrane lipids. Increasing TAs in chloroplast membranes has been shown to enhance low temperature tolerance in plants. The effects of elevated temperature degrees on fatty acids composition of storage lipids have been tested extensively in developing seeds. For example, the changes in soybean seed lipid composition under high temperatures (Wilson, 2004; Rajcan et al., 2005; Hou et al., 2006). Treatment with putrescine had resulted in a remarkable increase in palmitoleic acid (C16:1) compared with control untreated seeds at $25^{\circ} \mathrm{C}$. The induction of $\mathrm{C} 16: 1$ fatty acid in the yielded seeds of Trigonella may be attributed to the enhancement of desaturase activity which may desaturate C16:0 to C16:1. Replacement of C16:0 with C16:1 is presumably to maintain membrane fluidity and integrity. Application of putrescine to temperature stressed plants at $35{ }^{\circ} \mathrm{C}$ had a pronounced increase in the total unsaturated fatty acids $76.85 \%$

Table 1. Effect of Putrescine treatment on percentage of fatty acids of 120 days old Trigonella foenum-garcum seeds under temperature stress.

\begin{tabular}{|c|c|c|c|c|c|c|}
\hline Fatty acids & $25^{\circ} \mathrm{C}$ & putrescine & $15^{\circ} \mathrm{C}$ & $\begin{array}{c}15^{\circ} \mathrm{C}+ \\
\text { putrescine }\end{array}$ & $35^{\circ} \mathrm{C}$ & $\begin{array}{c}35^{\circ} \mathrm{C}+ \\
\text { putrescine }\end{array}$ \\
\hline Valeric acid C5:0 & 1.85 & 2.52 & 1.90 & 5.25 & 2.30 & 3.05 \\
\hline Caproic acid C6:0 & - & - & 1.50 & 1.50 & - & - \\
\hline Capric acid C10:0 & 1.72 & 1.95 & 1.75 & 2.70 & 2.02 & 2.60 \\
\hline Undecylic acid C11:0 & 1.85 & 2.35 & 4.20 & 2.50 & - & - \\
\hline Lauric acid C12:0 & 2.19 & 2.00 & 1.65 & 3.30 & 2.10 & 2.80 \\
\hline Myristic acid C14:0 & 3.85 & 2.25 & 3.90 & 3.25 & 2.00 & 2.55 \\
\hline Myristoleic acid C14:1 & - & 4.00 & 7.30 & - & 2.40 & 9.50 \\
\hline Palmitic acid C16:0 & 2.07 & 7.40 & 10.60 & 4.00 & 3.60 & 4.10 \\
\hline Palmitoleic acid C16:1 & 10.30 & 35.65 & 4.00 & 42.30 & 27.20 & 26.50 \\
\hline Margaric acid C17:0 & 2.53 & 2.35 & 2.30 & 5.85 & 3.35 & 3.40 \\
\hline Heptadecenoic acid C17:1 & 15.20 & - & - & - & 5.00 & 7.50 \\
\hline Stearic acid C18:0 & 26.30 & 12.45 & 4.35 & 4.85 & 18.00 & 4.65 \\
\hline Oleic acid C18:1 & 3.25 & 8.00 & 19.80 & 6.80 & 8.00 & 10.80 \\
\hline Linoleic acid C18:2 & 24.15 & 12.48 & 30.20 & 2.00 & 11.03 & 12.05 \\
\hline aLinolenic acid C18:3 & 3.24 & 4.35 & 4.00 & 11.20 & 10.30 & 10.50 \\
\hline Behenic acid C22:0 & 1.50 & 2.25 & 2.55 & 4.50 & 2.70 & - \\
\hline Total saturated fatty acids & 43.86 & 35.52 & 34.7 & 37.7 & 36.07 & 23.15 \\
\hline Total unsaturated fatty acids & 56.14 & 64.48 & 65.3 & 62.3 & 63.93 & 76.85 \\
\hline
\end{tabular}


compared with $63.93 \%$ at $35^{\circ} \mathrm{C}$. This may point out to the role of putrescine in stimulating desaturase activity of Trigonella yielded seeds. In addition, the substitution of saturated fatty acids with unsaturated fatty acids may indicate minimization of lipid peroxidation of the membrane. In this respect, Routaboul et al. (2000) found that maintenance of polyunsaturated fatty acids levels in chloroplast lipids had been shown to contribute to low temperature survival and the normal formation of chloroplast membranes under low temperature stress.

$\beta$-esterase zymogramme (Figure 6) revealed four esterase isoforms. Treatment with putrescine singly increased the thickness and intensity of all the enzyme isoforms compared with control. The applied temperature stress degrees $\left(15^{\circ} \mathrm{C}\right.$ and $\left.35^{\circ} \mathrm{C}\right)$ decreased the thickness and intensity of the enzyme isoforms which appeared with faint color especially at samples treated with $15^{\circ} \mathrm{C}$ compared with control. Application of putrescine with temperature stressed plants removed the harmful effects induced by temperature stress and this was reflected on the increase in thickness and intensity of $\beta$-esterase isoforms $\left(15^{\circ} \mathrm{C}+\right.$ put. and $35^{\circ} \mathrm{C}+$ put. $)$ compared with temperature stressed plants $\left(15^{\circ} \mathrm{C}\right.$ and $\left.35^{\circ} \mathrm{C}\right)$. In accordance with our results, Weng \& Chen (1989) stated that intense esterase bands may be used as a marker for high photosynthesis and grain yield ability in plants. Also, Charnay et al. (1992) found that polyamines have a role in all regulatory mechanisms in which esterases are involved.

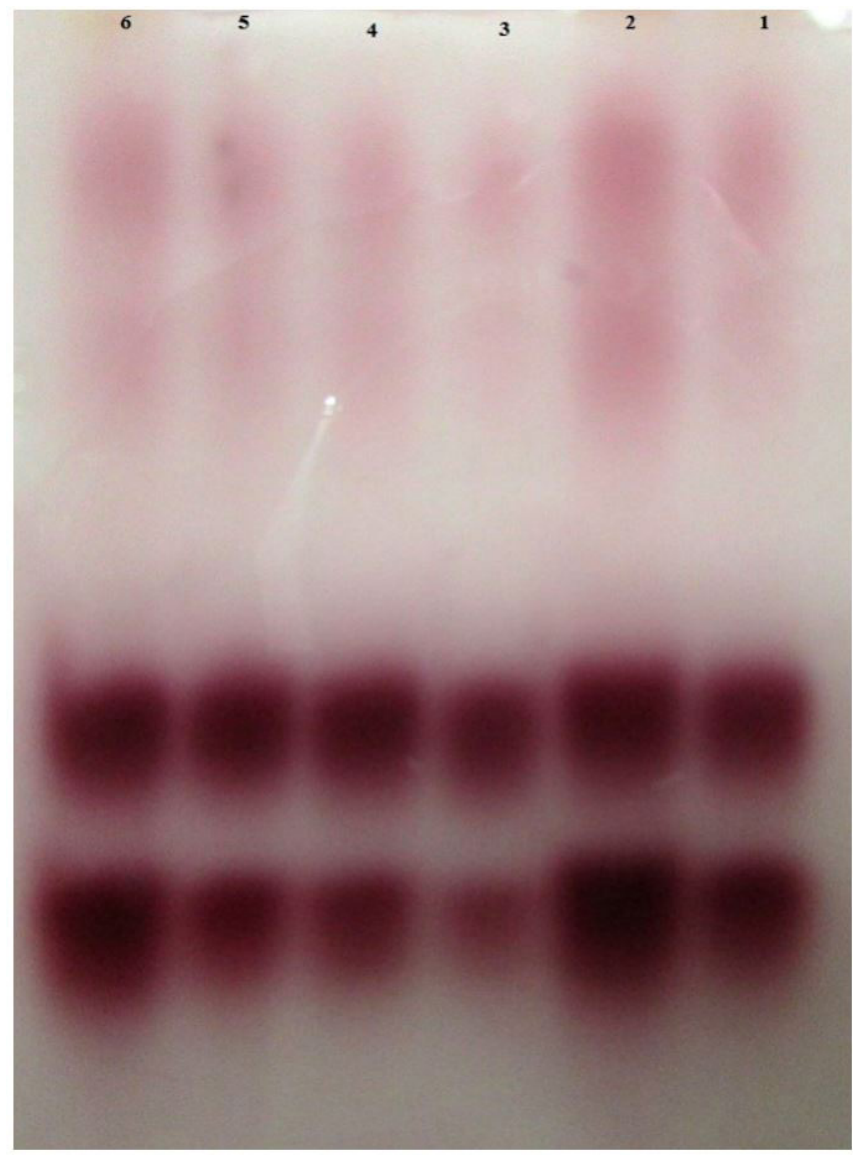

Figure 6. Effect of Putrescine on $\beta$-esterase zymogramme of 120 days old Trigonella foenum-garcum seeds under temperature stress ( $1=$ control; $2=$ Putrescine; $3=15^{\circ} \mathrm{C} ; 4=15^{\circ} \mathrm{C}+$ Put.; $5=35^{\circ} \mathrm{C} ; 6=35^{\circ} \mathrm{C}+$ Put. $)$.

\section{References}

Ahmad, P., Sarwat, M., \& Sharma, S. (2008). Reactive oxygen species, antioxidants and signaling in plants. Journal of Plant Biology, 51(3), 167-173. http://dx.doi.org/10.1007/BF03030694.

Ahmad, P., Ashraf, M., Younis, M., Hu, X., \& Kumar, A. (2011). Role of transgenic plants in agriculture and biopharming. Biotechnology Advances. http://dx.doi.org/10.1016/j.biotechadv.2011.09.006. PMid:21959304.

Bagni, N., \& Tassoni, A. (2001). Biosynthesis, oxidation and conjugation of aliphatic polyamines in higher plants. Amino Acids, 20(3), 301317. http://dx.doi.org/10.1007/s007260170046. PMid:11354606.

Bartels, D., \& Sunkar, R. (2005). Drought and salt tolerance in plants. Critical Reviews in Plant Sciences, 24(1), 23-58. http://dx.doi. org/10.1080/07352680590910410.

Barutcular, C., El-Sabagh, A., Koc, M., \& Ratnasekera, D. (2017). Relationships between grain yield and physiological traits of durum wheat varieties under drought and high temperature stress in Mediterranean environments. Fresenius Environmental Bulletin, 26(6), 4282-4291.

Beisson, F., Li, Y., Bonaventure, G., Pollard, M., \& Ohlrogge, J. (2007). The acyltransferase GPAT5 is required for the synthesis of suberin in seed coat and root of Arabidopsis. The Plant Cell, 19(1), 351-368. http://dx.doi.org/10.1105/tpc.106.048033. PMid:17259262.

Bhandari, K., Sharma, K. D., Hanumantha Rao, B., Siddique, K. H. M., Gaur, P., Agrawal, S. K., Nair, R. M., \& Nayyar, H. (2017). Temperature sensitivity of food legumes: a physiological insight. Acta Physiologiae Plantarum, 39(3), 68. http://dx.doi.org/10.1007/ s11738-017-2361-5.

Bharti, A., \& Khurana, J. (1997). Mutant of Arabidopsis as tools to understand the regulation of phenylpropanoids pathway and UVB protection mechanism. Journal of Photochemistry and Photobiology, 65(5), 765-776. http://dx.doi.org/10.1111/j.1751-1097.1997.tb01923.x. PMid:9155253.

Bishop, O. (1983). Statistics in biology (pp. 56-63). London: Longman Penguin.

Blée, E. (2002). Impact of phyto-oxylipins in plant defense. Trends in Plant Science, 7(7), 315-321. http://dx.doi.org/10.1016/S13601385(02)02290-2. PMid:12119169.

Bouchereau, A., Aziz, A., Larher, F., \& Martin-Tanguy, J. (1999). Polyamines and environmental challenges: Recent development. Plant Science, 140(2), 103-125. http://dx.doi.org/10.1016/S01689452(98)00218-0.

Bradford, M.M. (1976). A rapid and sensitive method for the quantification of microgram quantities of protein utilizing the principle of protein dye binding. Analytical Biochemistry, 72(1-2), 248-254. http://dx.doi. org/10.1016/0003-2697(76)90527-3. PMid:942051.

Chai, M., Li, R., Shi, F., Pan, L., \& Cao, D. (2012). Effects of cadmium stress on growth, metal accumulation and organic acids of Spartina alterniflora Loisel. African Journal of Biotechnology, 11(22), 6091-6099.

Charnay, D., Nari, J., \& Noat, G. (1992). Regulation of plant cell wall pectin methyl esterase by polyamines-Interactions with the effects of metal ions. European Journal of Biochemistry, 205(2), 711-714. http://dx.doi.org/10.1111/j.1432-1033.1992.tb16833.x. PMid:1572369.

Chen, D., Shao, Q., Yin, L., Younis, A., \& Zheng, B. (2019). Polyamine function in plants: metabolism, regulation on development, and roles in abiotic stress responses. Frontiers of Plant Science, 9, 19451953. http://dx.doi.org/10.3389/fpls.2018.01945. PMid:30687350. 
Dixon, R., Choudhary, A., Dalkin, D., Edwards, R., \& Fahrendorf, T. (1992). Molecular biology of stress-induced phenylpropanoid and isoflavonoid biosynthesis in alfalfa. In H.A. Stafford \& R.K. Ibrahim (Eds.), Phenolic metabolism in plants (pp. 91-138). New York: Plenum press. http://dx.doi.org/10.1007/978-1-4615-3430-3_4.

Garces, R., \& Mancha, M. (1993). One step lipid extraction and fatty acid methyl esters preparation from fresh plant tissues. Analytical Biochemistry, 211(1), 139-143. http://dx.doi.org/10.1006/abio.1993.1244. PMid:8323025.

Gaur, P., Saminen, S., \& Krishnamurthy, L. (2015). High temperature tolerance in grain legumes. Legume Perspectives, 7, 23-24.

Gottlieb, L. (1981). Electrophoretic evidence and plant populations. Progress in Phytochemistry, 7, 1-46.

Grechkin, A. (1998). Recent developments in biochemistry of the plant lipoxygenase pathway. Progress in Lipid Research, 37(5), 317-352. http://dx.doi.org/10.1016/S0163-7827(98)00014-9. PMid:10209652.

He, L., Nada, K., \& Tachibana, S. (2002). Effects of spermidine pretreatment through the roots on growth and photosynthesis of chilled cucumber plants (Cucumber sativus L.). Journal of the Japanese Society for Horticultural Science, 71(4), 490-498. http:// dx.doi.org/10.2503/jjshs.71.490.

Hou, G., Ablett, G., Pauls, K., \& Rajcan, I. (2006). Environmental effects on fatty acid levels in soybean oil. Journal of the American Oil Chemists' Society, 83(9), 759-763. http://dx.doi.org/10.1007/ s11746-006-5011-4.

Iba, K. (2002). Acclimative response to temperature stress in higher plants: approaches of gene engineering for temperature tolerance. Annual Review of Plant Biology, 53(1), 225-245. http://dx.doi. org/10.1146/annurev.arplant.53.100201.160729. PMid:12221974.

Jeong, H., Kim, H., Hong, S., \& You, Y. (2018). Effects of elevated $\mathrm{Co}_{2}$ concentration and increased temperature on leaf quality responses of rare and endangered plants. Journal of Ecology and Environment, 42(1), 1. http://dx.doi.org/10.1186/s41610-017-0061-0.

Jindal, K., \& Singh, R. (1975). Phenolic content in male and female Carica papaya: A possible physiological marker for sex identification of vegetable seedlings. Physiologia Plantarum, 33(1), 104-107. http:// dx.doi.org/10.1111/j.1399-3054.1975.tb03774.x.

Kacperska, A. (1993). Water potential alteration - A prerequisite or a triggering stimulus for the development of freezing tolerance in overwintering herbaceous plants. In P.H. Li \& L. Christerson (Eds.), Advances in plant cold hardiness (pp. 73-91). Boca Raton: CRC Press.

Kubis, J., Skoczek, H., \& Krzywanski, Z. (1991). Exogenous polyamines alter the activity of proteases, RNAses and membrane permeability in wheat leaves under water stress conditions. Acta Physiologiae Plantarum, 13, 139-146.

Kumar, A., Taylor, M., Altabella, T., \& Tiburcio, A. F. (1997). Recent advances in polyamine research. Trends in Plant Science, 2(4), 124130. http://dx.doi.org/10.1016/S1360-1385(97)01013-3.

Kumar, S., Nayyar, H., Bhanwara, R., \& Upadhyaya, H. (2010). Chilling stress effects on reproductive biology of chickpea. Journal of SAT Agricultural Research, 8, 1-14.

Kusano, T., Berberich, T., Tateda, C., \& Takahashi, Y. (2008). Polyamines: essential factors for growth and survival. Planta, 228(3), 367-381. http://dx.doi.org/10.1007/s00425-008-0772-7. PMid:18594857.

Laemmli, U. (1970). Cleavage of structural proteins during the assembly of the head of bacteriophage $\mathrm{T}_{4}$ Nature, 227(5259), 680-685. http:// dx.doi.org/10.1038/227680a0. PMid:5432063.

Lee, Y., \& Takahashi, T. (1966). An improved colorimetric determination of amino acids with the use of ninhydrin. Analytical Biochemistry, 14(1), 71-770. http://dx.doi.org/10.1016/0003-2697(66)90057-1.
Levine, A., Tenhaken, R., Dixon, R., \& Lamb, C. (1994). $\mathrm{H}_{2} \mathrm{O}_{2}$ from the oxidative burst orchestrates the plant hypersensitive disease resistance response. Cell, 79(4), 583-593. http://dx.doi.org/10.1016/00928674(94)90544-4. PMid:7954825.

Leyva, A., Jarillo, J., Salinas, J., \& Martinez-Zapater, M. (1995). Low temperature induces the accumulation of phenylalanine ammonialyase and chalcone synthase Mrna of Arabidopsis thaliana in lightdependent manner. Plant Physiology, 108(1), 39-46. http://dx.doi. org/10.1104/pp.108.1.39. PMid:12228452.

Liu, J., Kitashiba, H., Wang, J., Ban, Y., \& Moriguchi, T. (2007). Polyamines and their ability to provide environmental stress tolerance to plants. Plant Biotechnology (Sheffield, England), 24(1), 117-126. http:// dx.doi.org/10.5511/plantbiotechnology.24.117.

Mahmood, N., Abbasi, N., Hafiz, I., Ali, I., \& Zakia, S. (2017). Effect of biostimulants on growth, yield and quality of bell pepper cv. Yolo wonder. Pakistan Journal of Agricultural Sciences, 54(2), 311-317. http://dx.doi.org/10.21162/PAKJAS/17.5653.

Manchenko, G. (1994). Handbook of detection of enzyme on electrophoretic gels. Boca Raton, FL: CRC Press. Inc.

Naguib, M. (1963). Colorimetric estimation of plant polysaccharides. Zucker, 16, 15-18.

Naguib, M. (1964). Effect of sevin on carbohydrate and nitrogen metabolism during germination of cotton seeds. Indian journal of Experimental Botany, 2, 149-152.

Naguib, M., Youssef, E., \& Kinawy, M. (1968). Effect of kinetin on the nitrogen metabolism of radish plants. Bulletin of Faculty of Farmacy Cairo University, 42, 13-22.

Osman, M., El-Feky, S., Abo-Hamad, S., \& Seliem, H. (2015). Improvement of the harmful effects induced by temperature stress on Trigonella foenum-graecum L. by putrescine. The Egyptian Journal of Experimental Biology, 11(2), 197-205.

Palma, F., Carvajal, F., Jamilena, M., \& Garrido, D. (2016). Putrescine treatment increases the antioxidant response and carbohydrate content in zucchini fruit stored at low temperature. Postharvest Biology and Technology, 118, 68-70. http://dx.doi.org/10.1016/j. postharvbio.2016.03.009.

Pasteur, N., Pasteur, G., Bonhomme, F., Catalan, J., \& Britton, D. (1988). Practical isozymes genetics. The English. England: Ellis Horwood Ltd.

Perez-Amador, M. A., Leon, J., Green, P. J., \& Carbonell, J. (2002). Induction of the arginine decarboxilase ADC2 gene provides evidence for the involvement of polyamines in the wound response in Arabidopsis. Plant Physiology, 130(3), 1454-1463. http://dx.doi. org/10.1104/pp.009951. PMid:12428010.

Prasad, P., Pisipati, S., Mutava, R., \& Tuinstra, M. (2008). Sensitivity of grain sorghum to high temperature stress during reproductive development. Crop Science, 48(5), 1911-1917. http://dx.doi. org/10.2135/cropsci2008.01.0036.

Rajcan, I., Hou, G., \& Weir, A. (2005). Advances in breeding of seedquality traits in soybean. Journal of Crop Improvement, 14(1-2), 145-174. http://dx.doi.org/10.1300/J411v14n01_07.

Rivero, R., Ruiz, J., Garcia, P., Lopez-Lefebre, L., Sanchez, E., \& Romero, L. (2001). Resistance to cold and heat stress: accumulation of phenolic compounds in tomato and watermelon plants. Plant Science, 160(2), 315-321. http://dx.doi.org/10.1016/S0168-9452(00)00395-2. PMid:11164603.

Routaboul, J.M., Fischer, S., \& Browse, J. (2000). Trienoic fatty acids are required to maintain chloroplast function at low temperatures. Plant Physiology, 124(4), 1697-1705. http://dx.doi.org/10.1104/ pp.124.4.1697. PMid:11115886. 
Tajti, J., Janda, T., Majlath, I., Szalai, G., \& Pal, M. (2018). Comparative study on the effects of putrescine and spermidine pre-treatment on cadmium stress in wheat. Ecotoxicology and Environmental Safety, 148, 546-554. http://dx.doi.org/10.1016/j.ecoenv.2017.10.068. PMid:29127816.

Upchurch, R. (2008). Fatty acid unsaturation, mobilization, and regulation in response of plants to stress. Biotechnology Letters, 30(6), 967-977. http://dx.doi.org/10.1007/s10529-008-9639-z. PMid:18227974.

Weng, J., \& Chen, Y. (1989). Photosynthetic ability, grain yield and an esterase band in rice genotypes. Ecophytica, 42, 265-268.

Wilson, R. (2004). Seed composition. In H.R. Boerma \& J.E. Specht (Eds.), Soybeans: improvement, production, and uses (pp. 621-677). Madison: ASA.

Wink, M. (1997). Special nitrogen metabolism. In P.M. Dey \& J. Harborne (Eds.), Plant Biochemistry (pp 439-486). San Diego: Academic Press.
Wolf, R., Cavins, J., Kleiman, R., \& Black, L. (1982). Effect of temperature on soybean seed constituents: oil, protein, moisture, fatty acids, amino acids and sugars. Journal of the American Oil Chemists' Society, 59(5), 230-232. http://dx.doi.org/10.1007/BF02582182.

Yadav, S., Pavan, K., Tiwari, Y., Jainender, J., \& Jyothi, N. (2017). Exogenous application of bio-regulators for alleviation of heat stress in seedlings of maize. Journal of Agricultural Research, 2(3), 000137.

Yinghui, S., Min, Y., Sheng, Z., Nanshan, S., \& Lizhong, D. (2015). Effects of exogenous putrescine on leaf anatomy and carbohydrate metabolism in cucumber (Cucumis sativus L.) under salt stress. Journal of Plant Growth Regulation, 34(3), 451-464. http://dx.doi. org/10.1007/s00344-015-9480-2.

Zheng, Q., Zuo, J., Gu, S., Gao, L., Hu, W., Wang, Q., \& Jiang, A. (2019). Putrescine treatment reduces yellowing during senescence of broccoli (Brassica oleracea L. var. italica). Postharvest Biology and Technology, 152, 29-35. http://dx.doi.org/10.1016/j.postharvbio.2019.02.014. 